\title{
Legal Constraint of Genetic Use Restriction Technologies*
}

\author{
Dan L. Burk**
}

\section{INTRODUCTION}

Gene splicing techniques have enabled the creation of many types of sexually reproducing plants with commercially attractive characteristics: increased nutritional value, resistance to drought and pests, herbicide resistance, medicinal properties, and many other valuable attributes. ${ }^{1}$ In many quarters, such transgenic alterations to plant varieties have been controversial. But even more controversial has been the application of recombinant DNA technology to restrict the use of beneficial plant varieties. ${ }^{2}$ These genetic use restriction technologies, or GURTs, curtail the saving of seed from year to year by rendering the progeny of proprietary seed sterile. ${ }^{3}$ Although the deployment of this technology has for the moment been restrained by adverse publicity, continued research and continued commercial interest in its application suggest that it is a question of when, not whether, the technology will be deployed.

I have examined elsewhere the conceptual ramifications of this technology on intellectual property law and policy, and will not rehearse that discussion here. In this essay, I intend to focus upon the doctrinal issues undergirding an analysis of GURTs deployment. Here I examine the public policy factors

\footnotetext{
* Copyright 2004 by Dan L. Burk.

** Oppenheimer, Wolff \& Donnelly Professor of Law, University of Minnesota.

1. See Keith Aoki, Weeds, Seeds \& Deeds: Recent Skirmishes in the Seed Wars, 11 CARDOZO J. INT'L \& COMP. L. 247, 268-76 (2003).

2. See, e.g., Martha L. Crouch, Edmonds Institute, How the Terminator Terminates: An Explanation for the Non-Scientist of a Remarkable Patent for Killing Second Generation Seeds of Crop Plants (1998), at http://www.edmonds-institute.org/crouch.html (last visited Dec. 1, 2004).
}

3. See id. 
that determine the legitimacy or illegitimacy of proprietary rights licenses that cover plant varieties; I argue that these are the same factors that would be considered in determining whether equivalent GURTs usage is legitimate or illegitimate; and I look at the key American legal decisions that might guide us in determining the legitimacy of GURTs deployment. Unfortunately, as I demonstrate in detail below, the cases that purport to guide decision-makers in this area are poorly decided and incoherent even on their own terms, let alone when extended to new methods of plant variety use restriction. Consequently, we must be wary of any confident pronouncements regarding the acceptability of, or regarding the extension of, such practices to GURTs deployment.

\section{GENETIC USE RESTRICTION TECHNOLOGIES}

The economic challenge that impedes the development of new plant varieties is that plants naturally reproduce themselves. ${ }^{4}$ As a consequence, new varieties are relatively expensive to create, ${ }^{5}$ but are trivially inexpensive to propagate once they are in existence - and, indeed, may propagate unintentionally. This "public goods" problem of distribution at a marginal cost close to zero is common in other areas of innovation, even where the subject matter does not reproduce itself. ${ }^{6}$ Legal prohibitions have been the typical solution to this problem. ${ }^{7}$ In the United States, trade secrecy and utility patents have been used to secure exclusive rights in transgenic plant varieties, as has a specific form of intellectual property granting plant breeders' rights. The Plant Variety Protection Act (PVPA) 8 is specifically directed at encouraging development of new varieties of sexually reproducing plants by granting the developer broad control over the growth, use, importation, and

4. William W. Fisher, The Impact of Terminator Gene Technologies on Developing Countries: A Legal Analysis, in BIOTECHNOLOGY, AGRICULTURE, AND THE DEVELOPING WORLD: THE DISTRIBUTIONAL IMPLICATIONS OF TECHNOLOGICAL CHANGE 137, 139 (Timothy Swanson ed., 2002).

5. See id.

6. See generally William M. Landes \& Richard A. Posner, An Economic Analysis of Copyright Law, 18 J. LEGAL STUD. 325 (1989).

7. See generally Peter J. Goss, Guiding the Hand That Feeds: Toward Socially Optimal Appropriability in Agricultural Biotechnology Innovation, 84

CAL. L. REV. 1395 (1996) (reviewing legal protection for plant innovation).

8. Plant Variety Protection Act, 7 U.S.C. $\S \S 2321-2583$ (2000). 
sale of a new plant.9 This statute includes some important exceptions to a seed developer's control, such as provisions allowing farmers to save seed from a proprietary crop, ${ }^{10}$ or permitting agricultural research involving the plant. ${ }^{11}$

However, plant variety owners might prefer that their control over the variety not be subject to such exceptions. Patent rights and trade secrecy may also be exhausted or surrendered with the sale of the protected article. Consequently, as a condition of access to their seeds, owners routinely require that farmers contractually waive their rights to save seed or engage in other legally permissible uses. ${ }^{12}$ Often the terms of this contract are printed on or attached to the bag of seed; by using the seed, the contractual "fine print" purports that the farmer has agreed to the terms. ${ }^{13}$ However, it is difficult to police the use of seed and to enforce the terms of such "seed-wrap" licenses. To do so, seed developers must send agents out into farmers' fields to sample crops, looking for unlicensed users of proprietary seed. When such uses are found, costly legal procedures may be necessary to halt the use, force acceptance of a license, or recover unpaid royalties.

The problems of detection and enforcement might be lessened if seed could be designed to be "self-policing," that is, unsuitable for use without the developer's permission. GURTs allow for the creation of such "self-policing" seed. Genetic elements that produce a toxin late in seed development may be introduced into the plant variety. ${ }^{14}$ The toxin kills the seeds after the plant has matured, producing a viable crop for the farmer, but forcing him to return to the seed producer for new seed each year. ${ }^{15}$ Even in the absence of a contractual obligation not to save seed, the technology makes saving seed impossible. Thus, the genetically altered seed in essence carries within its own makeup a prohibition on unlicensed use.

Indeed, the prohibitions embedded in such genetic code may be quite sophisticated. In one embodiment of the technology, it is possible to introduce into the seed a genetic

9. See Aoki, supra note 1, at 284 .

10. See 7 U.S.C. $\$ 2543$.

11. See id. § 2544 .

12. See Mark D. Janis \& Jay P. Kesan, Intellectual Property Protection for Plant Innovation: Unresolved Issues after J.E.M. v. Pioneer, 20 NATURE BIOTECHNOLOGY 1161, 1163-64 (2002).

13. See id.

14. See Crouch, supra note 2.

15. See id. 
"switch" that will repress, or turn off, the toxin production when the seed is exposed to a particular chemical. ${ }^{16}$ This, in effect, supplies a chemical "password" to activate germination, which can be used to control the terms of seed usage from year to year. ${ }^{17}$ Yearly application of the control chemical, obtained from the seed owner for payment, would allow the owner to activate or deactivate seeds in return for prescribed payment. ${ }^{18}$ One can easily envision other types of switches, sensitive to temperature, precipitation, soil alkalinity, or other environmental factors, that could be used to limit use of the seed to certain geographical regions or seasonal applications. Indeed, plants could be engineered for various desirable properties - pest resistance, drought resistance, superior yield, and so on - and particular attributes activated or deactivated depending on the price paid by the purchaser.

The description of seed licensing offered above bears an uncanny resemblance to the history of content licensing in digital media. Copyright law affords the owners of digital content some recourse against many unauthorized uses of their material, 19 but copyright is subject to a host of consumer uses that require no authorization from the copyright holder. ${ }^{20}$ Owners of digital content, much like seed owners, have long wished to escape the consumer privileges afforded by copyright law. ${ }^{21}$ They have done so through the fiction of the massmarket or "shrink-wrap" license, which purports to restrict a purchaser's use of the accompanying product. ${ }^{2}$ But judicial treatment of these licenses has been mixed, ${ }^{23}$ and it is still extremely difficult for copyright holders to police such agreements. ${ }^{24}$ Consequently, copyright owners have begun deploying sophisticated software "lock-out" systems that prevent access to digitized content except on the terms dictated

16. See id.

17. $I d$

18. Id.

19. See Charles R. McManis, The Privatization (or "Shrink-Wrapping") of American Copyright Law, 87 CAL. L. REV. 173, 175 (1999).

20. See id. at 175-76.

21. See Mark A. Lemley, Intellectual Property and Shrinkwrap Licenses, 68 S. CAL. L. REV. 1239, 1266 (1995).

22. See id. at 1241-48; McManis, supra note 19, at 174.

23. See Lemley, supra note 21, at 1248-59; McManis, supra note 19, at 182-83.

24. See Lemley, supra note 21, at 1263. 
by the owner. ${ }^{25}$

The implications of this development are striking. As both Larry Lessig and Joel Reidenberg have pointed out, the design of technical standards confers upon the designer the power to govern behavior with regard to that system. ${ }^{26}$ Once constraints on behavior are built into the technical standards governing a technology, the technical standards effectively become a new method for governing use of that technology - in essence, the technical standards become a type of law. ${ }^{27}$ Such technical rule sets may supplement or even supplant the legal rule sets designed to govern the same behavior. ${ }^{28}$ The development of technological use controls, whether in software or transgenic corn, may substitute private technological rules for the public statutory rules declared by Congress in the Copyright Act 29 or PVPA. ${ }^{30}$ Where control over the design of information rights is shifted into the hands of private parties, those parties may or may not honor the public policies that animate public access doctrines such as fair use ${ }^{31}$ or a "farmer's exemption." 32 Rightsholders can effectively write their own intellectual property statute in either software or DNA. Producers who employ lockout technology may in essence become private legislatures, imposing rules of usage without regard to the broader public interest that informs democratic rule-making.

Since technical controls can impose conditions that formerly might have been the subject of a detailed license

25. See Dan L. Burk, Anticircumvention Misuse, 50 UCLA L. REV. 1095, 1132 (2003) [hereinafter Anticircumvention]; Dan L. Burk \& Julie E. Cohen, Fair Use Infrastructure for Rights Management Systems, 15 HARV. J.L. \& TECH. 41, 83 (2001); see generally Julie E. Cohen, Reverse Engineering and the Rise of Electronic Vigilantism: Intellectual Property Implications of "Lock-Out" Programs, 68 S. CAL. L. REV. 1091 (1995).

26. See LaWrence Lessig, Code AND Other LAWs of CyBerspace 86 (1999) (the design of Internet technology imposes the behavioral regulation on its users); Joel R. Reidenberg, Lex Informatica: The Formulation of Information Policy Rule Through Technology, 76 TEX. L. REV. 553, 554 (1998) ("Technological capabilities and system design choices impose rules on participants.").

27. See Reidenberg, supra note 26 , at 55 .

28. See LESSIG, supra note 26, at 213-30 (describing the interplay between technology systems and government regulation); Reidenberg, supra note 26 , at 55 (arguing the policymakers must understand technology networks in order to regulate them).

29. Copyright Act of 1976, 17 U.S.C. $\S \S 101-1332$ (2000).

30. Plant Variety Protection Act, 7 U.S.C. $\S \S 2321-2583$ (2000).

31. See 17 U.S.C. $\$ 107$ (2000).

32. $\quad$ See 7 U.S.C. $\S \S 2543-2544$ (2000). 
agreement, such controls might be viewed as equivalent to a sort of licensing regime. ${ }^{33}$ But such a comparison to contract law by no means justifies employment of technical controls that contravene established public policy. Carte blanche enforcement of private agreements has never been the rule in Anglo-American law. ${ }^{34}$ When such agreements are found illegal, unconscionable, or simply in violation of public policy, they are held unenforceable. ${ }^{35}$ Because contract law is state law, ${ }^{36}$ enforcement of a contract that would violate the public policy inherent in the federal intellectual property scheme, or embedded in the Constitution itself, is preempted. ${ }^{37}$

By the same token, if technical constraints mimic law, it may be that those mimicking illegitimate contractual terms should be considered prohibited, preempted, or void. This point has perhaps been argued most forcefully by Julie Cohen, who suggests that the coercive power of the state should be extended in support of technological constraints no farther than it may be to enforce statutory or contractual constraints. ${ }^{38}$ Stated differently, where federal law, public policy, or the Constitution impose limits on the government's creation and recognition of property rights in intellectual goods, those limits would apply equally to both legally and technologically delineated property. ${ }^{39}$

\section{THE LIMITS OF CODED REGULATION}

This equation of technology with law may seem at first somewhat abstract, so let me offer a fairly clear-cut scenario that illustrates the problem. Consider for example a patent license with a term that extends beyond the term of the underlying patent. The United States Supreme Court has long held that such licenses constitute per se patent misuse, as an attempt to extend the patent owner's exclusive rights beyond

33. See Maureen A. O'Rourke, Drawing the Boundary Between Copyright and Contract: Copyright Preemption of Software License Terms, 45 DUKE L.J. 479, 493-96 (1995).

34. See Mark A. Lemley, Beyond Preemption: The Law and Policy of Intellectual Property Licensing, 87 CAL. L. REV. 111, 158-71 (1999).

35. See id. at 151; O'Rourke, supra note 33, at 529.

36. See Lemley, supra note 34, at 158.

37. See id at 161-62; O'Rourke, supra note 33, at 528-34.

38. See Julie E. Cohen, Some Reflections on Copyright Management Systems and Laws Designed to Protect Them, 12 BeRKeley TeCH. L.J. 161, 172-79 (1997).

39. See id. 
the period set by Congress. ${ }^{40}$ This rule has been periodically vilified by commentators ${ }^{41}$ and by certain judges ${ }^{42}$ as economically irrational, but it remains the law. Even the United States Court of Appeals for the Federal Circuit, which has been notably hostile to the patent misuse doctrine, recognizes the continued viability of the rule. ${ }^{43}$

Presumably, then, a license directed to a patented plant variety, whether that license is a formally negotiated arm's length transaction or a mass-market "seed wrap" license attached to a bag of seed, would constitute patent misuse if the term of the license extends beyond the term of the patent. The license would likely be unenforceable on a variety of grounds, including pre-emption of the state-law contract by federal patent policy, being similarly void for public policy reasons, and perhaps even being unconscionable. Indeed, the underlying patent itself might be held unenforceable until the misuse constituted in the license was purged.

Consequently, the proper treatment of such a license seems relatively straightforward: it is unenforceable. The harder question is whether we would permit the deployment of genetic use restriction technology that accomplished essentially the same goal as the license: extending the exclusive rights of the patent holder beyond the term of the patent. Indeed, the exclusivity conferred by technological restriction may be far more complete than that conferred by a legally enforceable license: legal safeguards are far "leakier" than technological safeguards. ${ }^{44}$ Where exclusivity over a plant variety is conferred by a contract, the purchaser may decide to breach the agreement, risk detection of the breach, and risk possible enforcement of the agreement. But technical protections are not so easily ignored; absent a high degree of technological

40. See Morton Salt Co. v. G.S. Suppiger Co., 314 U.S. 488, 491 (1942) (“A patent operates to create and grant to the patentee an exclusive right to make, use and vend the particular device described and claimed in the patent. But a patent affords no immunity for a monopoly not within the grant ....").

41. See, e.g., Mark A. Lemley, Note, The Economic Irrationality of the Patent Misuse Doctrine, 78 CAL. L. REV. 1599, 1618-19 (1990) (criticizing the misuse doctrine on the grounds that the remedy unnecessarily rewards infringers).

42. See, e.g., USM Corp. v. SPS Technologies, Inc., 694 F.2d 505, 510 (7th Cir. 1982).

43. See Virginia Panel Corp. v. Mac Panel Co., 133 F.3d 860, 868 (Fed. Cir. 1997).

44. See Goss, supra note 7 (discussing the limitations of existing legal protections). 
sophistication, the purchaser will not have the option of ignoring an unwelcome, overreaching, or even illegal restraint on use of the plant variety. 45 Consequently, technological control over a patented plant variety could extend well beyond the life of a patent.

Note that this outcome could be contrived through a variety of strategies. Deployment of the GURT itself might confer an extended quasi-monopoly over use of the genetic invention so long as the technical protection is not easily circumvented and the entry of competing plant varieties into the market is impaired. More likely, the GURT might be coupled with contractual terms that extend the term of exclusivity beyond that of a patent. For example, the GURTprotected variety might be accompanied by a license that, rather than being directed to genetic improvement that is the subject of the expired patent, is directed to the GURT itself GURTs may themselves be patentable, and a license for use of a GURT-protected variety might effectively capture the value of a genetic modification protected by the GURT. The accompanying license might also be styled as permission to access the GURT-protected variety: GURTs can be designed to be deactivated by a particular chemical "password," and an accompanying license might purport to trade GURT deactivation for agreement not to save seed, reverse engineer the seed, and so on. ${ }^{46}$

This in turn suggests that the GURT-enabled license could be styled as a confidentiality agreement or license to use a trade secret. But treatment of an expired patent as a trade secret is problematic in a variety of aspects. The Supreme Court held long ago that state trade secrecy law is not preempted by Federal patent policy because the two cannot conflict. ${ }^{47}$ The Court reasoned that the election to patent an invention requires disclosure that would obviate trade secrecy. 48 In theory, a third party could follow the information disclosed in the patent - perhaps with the aid of materials publicly deposited by the patent holder - to create a competing version of the variety. But given the extreme concentration of the seed industry and the barriers to entry, ${ }^{49}$ such follow-on

45. See generally Crouch, supra note 2 .

46. See generally id.

47. See Kewaunee Oil Co. v. Bicron Corp., 416 U.S. 470, 493 (1974).

48. See id. at 490-93.

49. See Aoki, supra note 1, at 254-55 (noting that ten seed companies 
"generic" variety development may be infeasible. The initial developer of the variety may be able to maintain a position of market domination, particularly when locked into such a position by a combination of technological and licensing control.

In such a scenario, the status of the GURT-enabled license is unclear. While patent law as a general rule does not normally pre-empt trade secrecy, ${ }^{50}$ perhaps it would do so in this particular circumstance, or perhaps the license would be found unenforceable on other grounds. If so, perhaps the use of technology to achieve these same ends would be equally illegitimate, and fair game for circumvention. To the extent that circumvention of the GURT is prohibited by a patent covering the GURT, employment of that patent to effectively extend the exclusivity in the restricted variety might constitute misuse.

But in order to reach such a result, the technical protection must be considered equivalent to a prohibited or disfavored legal restriction. This requires sorting legitimate GURT deployment from illegitimate deployment, which in turn requires clear direction as to the public policy behind such exclusive rights. Several cases appear to deal with just these questions, addressing the licensing of plant varieties under patent and trade secrecy, as well as examining the interaction between these forms of intellectual property and the PVPA. Unfortunately, a review of the cases dealing with such rights indicates that they are anything but clear on the relevant policies that might be applicable to GURTs deployment.

\section{THE LIMITS OF TRADE SECRECY}

Use of valuable plant varieties could, in theory, be restricted by the law of real property, by withholding the variety from public access. This strategy would of course defeat the purpose and the incentive for developing new varieties. The legal analog to protection by seclusion is that of trade secrecy; the owner of the variety can legally prohibit or restrict access to property that is not generally available, even when restrictions on physical access to that property are not wholly feasible.51 GURTs allow the variety developer to achieve

control about forty percent of the global seed market).

50. See Pioneer Hi-Bred Int'l v. Holden Found. Seeds, Inc., 35 F.3d 1226, 1243 (8th Cir. 1994) (holding that patent and trade secret law can "peacefully coexist").

51. See UnIf. Trade Secrets ACT § 1(4)(1), 14 U.L.A. 433 (1985) ("Trade 
something quite similar, both distributing the variety and simultaneously restricting its use. ${ }^{52}$ Restriction of plant variety usage via GURTs or GURTs-enabled licenses may most closely parallel protection via trade secrecy, and so the treatment of plant varieties under trade secrecy may give some guidance as to their treatment vis a vis GURTs.

At least one U.S. court has held that the genetic composition of proprietary seed is protectable as a trade secret, although under facts and procedural circumstances that could limit the decision's wider applicability. In Pioneer Hi-Bred International $v$. Holden Foundation Seeds, Inc., ${ }^{53}$ the Eighth Circuit Court of Appeals upheld a trial court award of damages for misappropriation of the "genetic message" contained in hybrid seed corn. ${ }^{54}$ The defendant, Holden, was accused of developing hybrid corn from misappropriated Pioneer seed lines. ${ }^{55}$ Expert testimony regarding the accused seed suggested that it was genetically related to the proprietary seed, and most likely derived from the proprietary seed. 56 Holden was unable to show that it did not derive its seed from Pioneer's. Although Holden did show evidence that Pioneer's seed had been publicly available on some occasions, ${ }^{57}$ it did not show that it had obtained Pioneer seed from public sources. ${ }^{58}$ The court held that absent a showing that the accused seed was obtained via publicly available sources, an inference could be drawn that access to the seed came via improper means. ${ }^{59}$

This result is troubling due to the court's position that genetic information, even in grain that may have been publicly accessible, was rendered proprietary by the developer's expenditures on confidentiality. 60 This result depends upon on older trade secrecy cases, grounded in the Restatement of Torts, ${ }^{61}$ holding that public availability of a purported trade

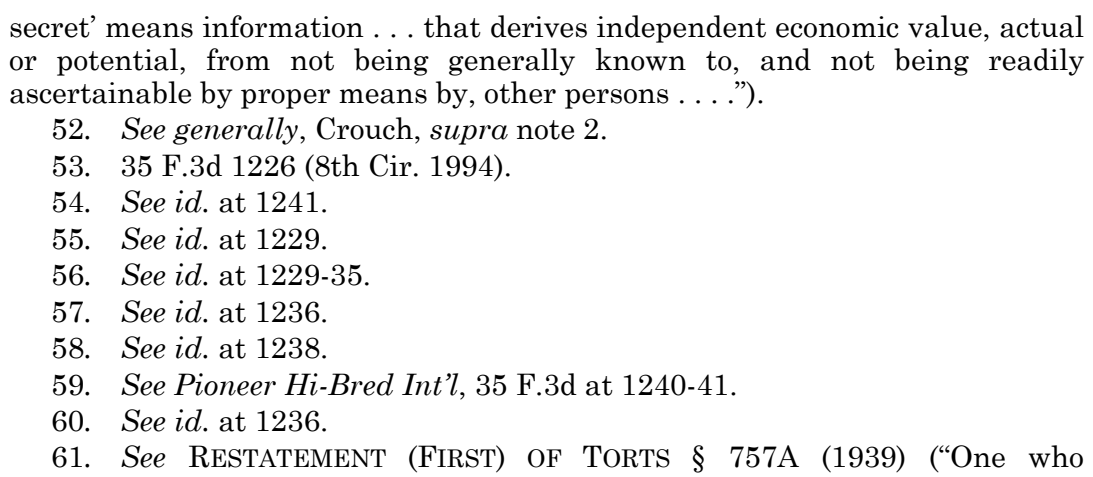


secret is relevant only if the defendant in fact obtained the information from those public sources. ${ }^{62}$ This conclusion probably would not have been reached under more recent conceptions of trade secrecy law, such as the Uniform Trade Secrets Act, ${ }^{63}$ which indicates that information does not qualify for trade secrecy if it is either "generally known" or "readily ascertainable by proper means." 64 Indeed, as the court in Holden itself recognized, and as I have articulated at greater length elsewhere, 65 trade secrecy interpreted in such a manner may well run afoul of federal patent policy by withdrawing from the public domain unpatented and unpatentable information that the federal patent system intends for public availability. 66

The defendant in Holden also argued that the federal PVPA preempted trade secret protection of the proprietary hybrid seeds. ${ }^{67}$ The Eighth Circuit rejected this argument, stating first that the legislative history of the PVPA showed no evidence that Congress intended to preempt state plant variety protection. ${ }^{68}$ Citing the Supreme Court holding in Kewanee Oil Co. v. Bicron Corp. ${ }^{69}$ for the proposition that patent and trade secret can "peacefully coexist,"70 the appellate court in Holden implied - alas, without analysis - that the federal PVPA and state trade secrecy could similarly coexist. ${ }^{71}$

discloses or uses another's trade secret, without a privilege to do so, is liable to the other if (a) he discovered the secret by improper means").

62. See, e.g., E.I. duPont deNemours \& Co. v. Christopher, 431 F.2d 1012 (5th Cir. 1970).

63. UNIF. TRADE SECRETS ACT, 14 U.L.A. 433 (1985).

64. Id. § 1(4)(1) ("Trade secret' means information . . . that derives independent economic value, actual or potential, from not being generally known to, and not being readily ascertainable by proper means by, other persons . . . ."); see also RESTATEMENT (THIRD) OF UNFAIR COMPETITION § 39 cmt. f (1995) (stating that information that is "generally known" or "readily ascertainable through proper means" by others is not protectable as a trade secret).

65. See Dan L. Burk, Misappropriation of Trade Secrets in Biotechnology Licensing, 4 ALBANY L.J. SCI. \& TECH. 121, 126-28, 130 (1994); see also Kewaunee Oil Co. v. Bicron Corp., 416 U.S. 470 (1974).

66. Burk, supra note65, at 126-128, 130 .

67. See Pioneer Hi-Bred Int'l v. Holden Found. Seeds, Inc., 35 F.3d 1226, 1242 (8th Cir. 1994).

68. See id. at 1243

69. 416 U.S. 470 (1974).

70. See Pioneer Hi-Bred Int'l, 35 F.3d at 1243 (citing Kewanee Oil, 416 U.S. at 474).

71. See id. 
The court's cursory recitation on preemption indeed tracks the correct form of a preemption inquiry, ${ }^{72}$ although perhaps telescoping some steps of the analysis together. Where state and federal regulations overlap, a court properly asks as an initial matter whether the statute contains explicit language indicating Congressional intent to preempt state law. ${ }^{73}$ If such language is found, the court must still determine the scope of preemption, but need not infer intent to preempt. ${ }^{74}$ If there is no explicit language regarding preemption, the court must infer whether or not Congress intended to preempt state law. 75 Preemption, whether express or implied, may constitute either "field" preemption, in which Congress intends to eject the states from the entire field of regulation at issue, ${ }^{76}$ or "conflict preemption," in which the particular statue at issue conflicts with some Congressional objective embodied in a federal statute. ${ }^{77}$ In the latter case the particular state regulation is invalidated, although other, non-conflicting state regulations might be permissible. ${ }^{78}$ Conflicts are often detected by asking whether the state statute either "stands as an obstacle" to a federal purpose or disrupts the "delicate balance" struck by Congress in fashioning the federal statute. ${ }^{79}$

In holding that the federal PVPA and state trade secrecy can "peacefully coexist," the Eighth Circuit recites a conclusion that implies conflict preemption analysis. But the superficial treatment in Holden unfortunately lacks the substance to actually resolve the question posed; it reaches a conclusion regarding conflict preemption, but on grounds that sound in field preemption. Certainly the PVPA contains no express language regarding preemption, either in the legislative history or in the statute itself. Turning then from express preemption to implied preemption, it indeed seems unlikely that Congress intended entirely to eject the states from the field 80 of plant variety protection - such field preemption is relatively rare and typically occurs in matters of uniquely national or federal

72. See id. at 1242 .

73. See Dan L. Burk, Protection of Trade Secrets in Outer Space Activity: A Study in Federal Preemption, 23 SETON HALL L. REV. 560, 597 (1993).

74. See id.

75. See id. at 599.

76. See id.

77. See id. at 606.

78. See id.

79. See Burk, supra note 73 , at 606 .

80. Perhaps an unfortunate metaphor in this instance. 
concern, where there is simply no room for states to engage in regulation. ${ }^{81}$ Plant variety protection would not seem to be such a uniquely federal area, nor is federal regulation so pervasive as to exclude any opportunity for state regulation of the matter.

But this does not answer the question as to whether state trade secrecy law, or even the contract on which trade secrecy may be premised, stands as an obstacle to federal policy, requiring application of narrower conflict preemption. This inquiry is based not on explicit statements by Congress, but by the structure, purposes, and effects of the federal statute considered. ${ }^{82}$ If the state regulation frustrates Congressional purposes, then the court should infer that Congress intended or would have intended preemption. ${ }^{83}$ There exists a very real possibility that trade secrecy presents such an obstacle. For example, the PVPA contains an explicit research exemption, allowing protected varieties to be used in the development of new varieties. ${ }^{84}$ The facts of the Holden case involve just such varietal development.85 Extension of trade secrecy to the development of new varieties could well block Congressional intent to further such research. Moreover, the research provisions exist as a result of the Congressional compromises negotiated among the parties affected by the PVPA. Application of trade secrecy could be seen as disturbing the "delicate balance" struck by Congress among the competing interests of seed owners, farmers, and follow-on researchers.

Neither is the Supreme Court analysis regarding patent law and trade secrecy especially helpful-much less dispositive-where a different statute, embodying different policies, is concerned. Much of the holding in Kewanee rested upon the assumption that trade secrecy will never divert eligible information from the patent system, ${ }^{86}$ and that the choice between patent and trade secrecy is binary: information publicly disclosed in order to obtain a patent cannot be kept as a secret, 87 forcing inventors to make an election between the

81. See Burk, supra note 73 , at 599 .

82. See id. at 606 .

83. See id. at 606-07.

84. See 7 U.S.C $\$ 2544$ (2000).

85. See Pioneer Hi-Bred Int'l v. Holden Found. Seeds, Inc., 35 F.3d 1226, 1228-29 (8th Cir. 1994).

86. See Kewanee Oil Co. v. Bicron Corp., 416 U.S. 470, 489-90 (1974).

87. See id. at 481. 
two. The first part of this assumption is a questionable hypothesis, even for the patent system. Trade secrecy is subject to cessation due to independent discovery or reverse engineering, 88 but can in theory last perpetually, so long as the information remains undisclosed. 89 Thus the inventor's choice is an election between twenty years of certain patent protection or perpetual, but less certain, trade secret protection-a choice that in any given instance hardly can be said to have a foregone outcome.

But the second assumption of Kewanee-that the election of protection must be either patent or trade secrecy due to disclosure - is entirely inapplicable to the PVPA context. Inventions can be kept either as a patent or as a trade secret; the choice to patent by definition destroys trade secrecy. From the standpoint of disclosure, the election is binary, so that only one mode of protection can be operating at a time, and there is no opportunity for interference between the two. But plant variety protection does not necessarily put a varietal developer to such an election of disclosure or non-disclosure. Indeed, a more recent case, Advanta USA, Inc. $v$. Pioneer Hi-Bred International, Inc. ${ }^{90}$ rests its mistaken preemption holding on precisely this observation. Rejecting a PVPA preemption challenge to Wisconsin trade secrecy law, the U.S. District Court for the Western District of Wisconsin held that because the PVPA does not require detailed disclosure, there is no actual conflict between concurrent PVPA and state trade secrecy protection of hybrid plants. ${ }^{91}$

Consequently, the Kewanee rationale tells us little about whether the PVPA and trade secrecy can peacefully co-exist; there is no required election between the two. The court in Advanta failed to consider that the state law might stand as an obstacle to the purposes of federal statute, and that under the logic of Kewanee, the lack of actual conflict may signal the presence of a conflict with Congressional "purpose or objective."92 Trade secrecy could well operate simultaneously with the PVPA to frustrate the function of the statute; and, to

88. See Burk, supra note 73 , at 589.

89. See id.

90. No. 04-C-238-S, slip op. (W.D. Wisc. Oct. 27, 2004).

91. Id. at $18-20$.

92. Id. Indeed, when combined with the Supreme Court's result in J.E.M. $v$. Pioneer Hi-Bred, this result effectively writes the PVPA out of existence. See infra note 118 and accompanying text. 
the extent that GURTs function as a technological equivalent to trade secrecy, they may do the same. Trade secrecy could well operate simultaneously with the PVPA to frustrate the function of the statute; and, to the extent that GURTs function as a technological equivalent to trade secrecy, they may do the same.

\section{THE LIMITS OF OVERLAPPING EXCLUSIVITY}

The question raised in Holden as to the potential for overlapping regimes of protection also arises with regard to patent law and plant variety protection. In the case of overlapping utility patents, however, limitations will arise out of horizontal conflicts between the two federal statutes, rather than vertical conflicts between a federal statute and a state statute. The permissibility of overlapping patent and PVPA protection has been addressed by the United States Supreme Court in the much-ballyhooed decision J.E.M. Ag Supply, Inc. $v$. Pioneer Hi-Bred International,93 where the defendant, accused of saving seed in violation of a patent-based "seedwrap" license, challenged the propriety of utility patent protection for plants. ${ }^{94}$ The applicability of utility patents to plant varieties was upheld by the Court in an astonishingly badly reasoned opinion authored by Justice Thomas. ${ }^{95}$ Although the analytical sins of the opinion are legion, I shall focus only upon the two most directly germane to the question of GURTs deployment.

The first of these deals with overlapping intellectual property regimes. The J.E.M. opinion both assumes and asserts that intellectual property regimes with overlapping subject matter are quite routine, even unremarkable. ${ }^{96}$ To support this proposition, Justice Thomas relies upon citations to the Court's previous opinions in Kewanee Oil and Mazer $v$. Stein. ${ }^{97}$ But these decisions are at best irrelevant, and may indeed point in the opposite direction from Justice Thomas' claim. Neither case in fact dealt with overlapping intellectual property regimes. In Kewanee Oil v. Bicron Corp., ${ }^{98}$ the Court

93. 534 U.S. 124 (2001).

94. See J.E.M. Ag. Supply, Inc., 534 U.S. at 128-29.

95. See id. at 145 .

96. See id. at 144 .

97. Id. (citing Kewanee Oil Co. v. Bicron Corp., 416 U.S. 470, 484 (1974) and Mazer v. Stein, 374 U.S. 201, 217 (1954)).

98. 416 U.S. 470 (1974). 
held that state trade secrecy law is not preempted by the federal intellectual property; 99 but this result was based on the assumption that the two forms of intellectual property protection are mutually exclusive: to obtain patent protection, one must disclose the invention in the published patent document, thus forgoing trade secrecy. ${ }^{100}$

Similarly, Mazer $v$. Stein ${ }^{101}$ considered the division between what have traditionally been the subject matters of patent and copyright - the utilitarian and the aesthetic. ${ }^{102}$ But far from allowing the two to overlap, the opinion keeps them distinctly compartmentalized. The opinion in Mazer is famous for establishing the rule that functional aspects of copyrightable works are not covered by copyright. ${ }^{103}$ Only aesthetic portions of the work, to the extent that they are physically or conceptually separable from the work's functional aspects, can be protected by copyright. 104 And, in order to keep the two intellectual property regimes separate, should the utilitarian and aesthetic portions of the work prove inseparable or inextricably co-mingled, copyright protection becomes unavailable. 105

The inapposite nature of these decisions to Justice Thomas's reasoning is not only ironic, but altogether prophetic with regard to overlapping patent protection for transgenic plants. The rule established in Mazer has proven to be exceptionally important for software, which is one of the very rare artifacts that can be simultaneously subjected to both the patent and copyright regimes. Copyright has no purchase impact on software to the extent that it is functional-only the literal code and non-functional aspects of its structure can be protected by copyright.106 This in turn allows copyright's fair use doctrine ${ }^{107}$ to provide an effective reverse engineering

99. See Kewanee Oil Co., 416 U.S. at 493.

100. See id. at 491-92.

101. 347 U.S. 201 (1954).

102. See Mazer, 347 U.S. at 211-19.

103. See id. at 218 ("We find nothing in the copyright statute to support the argument that the intended use or use in industry of an article eligible for copyright bars or invalidates its registration").

104. See id. (discussing the clear distinction between copyright and patent law).

105. Id.

106. See Dan L. Burk, Patenting Speech, 79 Tex. L. REV. 99, 130-35 (2000).

107. See generally Maureen A. O'Rourke, Toward a Doctrine of Fair Use in Patent Law, 100 CoLUM. L. REV. 1177, 1181-1211 (2000). 
privilege for software. 108 Courts have held that the creation of intermediate or temporary copies, made in the course of accessing uncopyrighted and unprotectable aspects of the program, is fair use. 109

To the extent that patent law may be available to protect a computer program's functional aspects, it may serve to override or negate this reverse engineering privilege. ${ }^{110}$ Patent law includes no fair use provision, 111 nor indeed much else in the way of user privileges or exemptions. ${ }^{112}$ This has been a source of concern to commentators reviewing the state of the software industry, as software innovation depends upon interoperability, 113 and patents may serve to block the development of interoperable products. ${ }^{114}$ The introduction of a fair use doctrine, or its equivalent, into patent law has been suggested to alleviate this problem. ${ }^{115}$

The negation of exemptions and privileges by overlapping patent protection in software is precisely the same problem elided by the Court in J.E.M.; ${ }^{116}$ and this leads us to the second key analytical flaw in the opinion. Much of the holding in J.E.M. rested upon the questionable conclusion that the patent and PVPA statutes are in some fashion compatible, 117 so that no inference might be drawn that Congress did not intend the two statutes to overlap. ${ }^{118}$ But in fact this conclusion of

108. See Julie E. Cohen \& Mark A. Lemley, Patent Scope and Innovation in the Software Industry, 89 CAL. L. REV. 3, 17 (2001).

109. See O'Rourke, supra note 107, at 1220-21 (citing Atari Games Corp. v. Nintendo of America Inc., 975 F.2d 832 (Fed. Cir. 1992) and Sega Enters. Ltd. v. Accolade, Inc., 977 F.2d 1510 (9th Cir. 1992)).

110. See Cohen \& Lemley, supra note 108, at 17-21.

111. See id. at 6.

112. See id. at 6.

113. See Cohen, supra note 25, at 1093.

114. See Cohen \& Lemley, supra note 108, at 5-6.

115. See id. at 37; O'Rourke, supra note 107, at 1230-35; see also Burk, supra note 106, at 151-58.

116. See J.E.M. Ag Supply, Inc. v. Pioneer Hi-Bred Int'l, Inc., 534 U.S. 124, 140 (2001)

117. See id. at 140-41.

118. And indeed, when combined with cases holding that there is no conflict between the overlap of PVPA and trade secrecy essentially reads PVPA out of existence: if a plant developer has the election between robust patent protection for 20 years, or perpetual protection under trade secrecy, it is difficult to see when he would ever opt for PVPA protection that is shorter than trade secrecy and weaker than patent. See supra note 92 and accompanying text. Some commentators have suggested that PVPA is indeed unnecessary and redundant. See generally Mark D. Janis and Jay P. Kesan, 
compatibility is blatantly wrong in a number of respects, particularly in that patent protection is entirely incompatible with the research and farmer's exemptions in the PVPA. The overlay of patent law onto PVPA subject matter negates these exemptions in the same fashion that patent protection overrides the reverse engineering exemption for software. Whatever public benefit or constituent balance Congress intended for the exemptions is thus lost, much as it would be with the overlay of GURTs upon plant varieties.

This problem is not new to Supreme Court jurisprudence; indeed, overlapping intellectual property protection has posed a problem in a variety of situations where one form of intellectual property threatens to disrupt the substantive limits or policy balance of another. Instead of looking to the inapposite Kewanee Oil and Mazer decisions, the Court in J.E.M. might better have looked to Supreme Court precedent in the area of trademark law, where the court has repeatedly expressed its concern that overlapping patent and trademark protection not be permitted to disrupt federal patent policy. ${ }^{119}$ While the term of patent protection has been carefully limited by Congress, 120 trademark or trade dress protection can last as long as the owner of the mark continues to use it in commerce theoretically forever. ${ }^{121}$

The Court has repeatedly held that one form of intellectual property cannot be used to subvert the limits of another. In Kellogg Co. v. National Biscuit Co., ${ }^{122}$ the Court held that consumer recognition of a distinctively shaped "shredded wheat" biscuit could not be used under law of trademark to extend a patent owner's rights beyond the term of the patent on the biscuit. ${ }^{123}$ The Court reaffirmed that principle with regard to distinctively shaped traffic sign assemblies in Traffix Devices, Inc. v. Marketing Displays, Inc. ${ }^{124}$ - a case decided just

U.S. Plant Variety Protection: Sound and Fury . . .?, 39 Hous. L. REV. 727 (2002). But the statute does exist, and until Congress repeals it, demands that the intellectual property system should be envisioned so as to give it effect.

119. See, e.g., Qualitex Co. v. Jacobson Products Co., 514 U.S. 159, 164-65 (1995) (explaining patent concerns underlying the trademark functionality doctrine).

120. See 35 U.S.C. $\S 154(a)(2)(2000)$.

121. See 15 U.S.C. $\S 1058$ (2000).

122. 305 U.S. 111 (1938).

123. See id. at 119-20.

124. 532 U.S. 23, 35 (2001). 
before J.E.M., but curiously not mentioned in the opinion. The principle is not limited to patent law; in Dastar Corp. $v$. Twentieth Century Fox Film Corp.,125 the Court held that documentary films for which copyright had lapsed could not be protected under the Lanham Act's false designation of origin provision. ${ }^{126}$ The reasoning in J.E.M. sits uncomfortably amid these decisions, offering little indication that the confluence of patent and PVPA protection is more acceptable than the confluence of patent and trademark, or copyright and trademark.

\section{THE LIMITS OF SEEDWRAP LICENSING}

The question of overlapping patent and PVPA protection in turn implicates the licensing of patented plant varieties. The jurisprudence of utility patent licensing for plants could closely parallel the employment of GURTs and GURTs-enabled licenses for plants, either because the technological protection confers exclusivity analogous to patent protection, or because the GURT itself is patented, and tampering with it may trigger patent liability. Patent rights are extensive, but they are not unlimited, and their exercise may be constrained by the doctrines of exhaustion, misuse, or by antitrust considerations. ${ }^{127}$ These doctrines might similarly be recruited to constrain analogous GURTs deployment.

The limitations on patent "seedwrap" licensing have been addressed in the Monsanto Co. v. McFarling (McFarling I) $)^{128}$ litigation, another lawsuit dealing with seed saved in violation of a "seedwrap license."129 Prominent among defendant McFarling's arguments against the enforceability of the license was that of patent exhaustion: the patentee's loss of right in a particular patented item after it is sold.130 Patent exhaustion is often compared to the first sale doctrine in copyright, ${ }^{131}$ as each constitutes a mechanism of a more general policy disfavoring restraints on alienation. In each case, an

125. 539 U.S. 23 (2003).

126. See Dastar Corp., 539 U.S. at 38.

127. Id. at 662-63; United States v. Univis Lens Co., 316 U.S. 241, 251-52, (1942).

128. 302 F.3d 1291 (Fed. Cir. 2002).

129. See McFarling I, 302 F.3d at 1294.

130. See id. at 1298.

131. ROBERT E. MERGES \& JOHN F. DUFFY, PATENT LAW AND POLICY: CASES AND MATERIALS 1023 (3d ed. 2002). 
intellectual property owner's rights in the physical object sold to another are exhausted, although the intellectual property rights in the intangible work remain. In the particular case of patent exhaustion, the patent owner's rights to a particular embodiment of the claimed invention are exhausted after transfer, although he may still hold the right to prevent making, use, sale, offering for sale, or importation of the claimed invention. ${ }^{132}$

But patent law differs from copyright in an important respect. In copyright, the division between the exclusive rights in the work and the right to dispose of the copy are relatively pristine. Copyright excludes only certain uses of the tangible copy, ${ }^{133}$ and first sale speaks to only one of these, the right of distribution. ${ }^{134}$ But unlike copyright's first sale doctrine, patent law's exhaustion doctrine is entangled with the exclusive rights of the patent owner, which include the right to exclude all uses. ${ }^{135}$ Thus, sale of a patented item is typically assumed to entail a license for the normal and customary "use" of the product - the purchaser would be highly unlikely to purchase a product which he was excluded from using in any manner whatsoever.

In challenging the Monsanto "seedwrap" agreement, McFarling argued that Monsanto's rights in the seeds and their progeny were exhausted upon sale of the seed. ${ }^{136}$ The Federal Circuit looked to their recent jurisprudence holding that patent exhaustion can be negated by explicit terms in the sale or license of the patented product, reasoning that the restrictions in the "seedwrap" license covered the seeds actually sold, and that the sale of the seeds conferred no implicit or explicit license to "construct new seeds." 137 Further, the court held that the new, second generation seeds themselves were not subject to exhaustion, because they were not sold to MacFarling, but were "made" by him from the first generation seeds that were

132. See United States v. Univis Lens Co., 316 U.S. 241, 249-50 (1942); United States v. Masonite Corp., 316 U.S. 265, 279 (1942); Intel Corp. v. ULSI Sys. Tech., 995 F.2d 1566, 1568 (Fed. Cir. 1993).

133. See 17 U.S.C. $\S 102($ a) (2000).

134. See id. §109(a).

135. See 35 U.S.C. $§ 271$ (2000).

136. See Monsanto Co. v. McFarling, 302 F.3d 1291, 1298 (Fed. Cir. 2002) [hereinafter McFarling I].

137. See id. at 1298-99 (citing B. Braun Medical, Inc. v. Abbott Laboratories, 124 F.3d 1419 (Fed. Cir. 1997)). 
sold. 138

This analysis is at best confused, failing to separate the interconnected issues raised by McFarling's claim. The Federal Circuit plausibly answers the question as to whether the patent holder's rights in the first generation seed were exhausted, but simultaneously sidesteps the question of whether the patent holder's rights in the second generation seeds were exhausted. It is simply contradictory and nonsensical for the court to state that the sale conferred only the right to use the original seeds, and that the "original sale of the seeds did not confer a license to construct new seeds."139 Using the original seeds necessarily entails the construction of new seeds; that is how seeds work. Soybeans in particular would be worthless if the license to use them did not confer a license to "construct new seeds"; i.e., a second generation of soybeans to be harvested. Although this may not necessarily be true of some other plants, such as cotton or flax, where the plant itself, rather than its seeds, is the desired product. ${ }^{140}$ But in the case of soybeans, the sale of the initial seeds must necessarily confer a license to "construct new seeds." There is no other reason for the farmer to have purchased them.

Consequently, the question cannot be what usage constraints were placed upon the first generation seeds clearly they were to be used to generate additional seeds. The question is rather the legitimacy of the constraints imposed in the contract for sale of the first generation seeds upon the use of the second generation seeds, constraints requiring the purchaser to use the second generation seeds for food or another end product, and not for planting. This is clearly a matter of imposing terms upon the purchaser of one product regarding another product not yet in existence at the time of the first product's sale. Stated differently, the legitimacy of the transaction depends upon whether the license for the use of the first generation seeds can permissibly "reach through" to constrain the use of the second generation seeds.

The court seems to have realized this mistake, at least in part, in its subsequent McFarling II opinion addressing McFarling's appeal from summary judgment, in which McFarling claimed that the terms of the license constituted a patent misuse, tying a license for the first generation seeds to a

138. See id. at 1299 .

139. Id.

140. Id. 
license for the second generation seeds.141 There the Federal Circuit acknowledged that McFarling would plant and harvest the first-generation seeds in the identical fashion, whether he planned to replant the second generation seed or not;142 consequently, the license must be imposing a prohibition on the use of the second generation seed rather than on the first generation seed.143 However, the court sidestepped the applicability of such a license to the second generation seeds, reasoning that since they must necessarily fall within the patent claims, a prohibition on their use fell within the scope of the patent. ${ }^{144}$ Hence, the prohibition could not constitute misuse.

It is worth noting that the use of upstream patent licenses to constrain use of downstream products has become an issue of concern in other technologies, particularly in the pharmaceutical industry, where some commentators have suggested that the practice implicates both antitrust and patent misuse. ${ }^{145}$ In the case of patented seed licenses, the analysis is somewhat more complex; as the court noted in McFarling II, the derived product will always fall within the scope of the patent, ${ }^{146}$ which may or may not be the case with research products. But even though the second generation seeds saved by McFarling fell within the scope of the Monsanto patent, this does not answer the question as to whether the licenses for the first and second generation seeds were tied, let alone whether they were impermissibly tied. The analysis I have reviewed here demonstrates that a constraint on the use of the second generation seeds would constitute at least partial revocation of the implied license to use the second generation seeds, arising out of the license for the first generation seeds. If the licenses for each type of seed use can be said to function in different markets, and Monsanto's market power in the market for first generation seeds is being used to leverage market power in the market for second generation seeds, then an argument for antitrust violation is at least feasible-and antitrust violations are per se misuse.

141. Monsanto Co. v. McFarling, 363 F.3d 1336, 1341 (Fed. Cir. 2004) [hereinafter McFarling II].

142. See id. at 1342 .

143. See id. at 1342-43.

144. See id. at 1343.

145. See Robin C. Feldman, The Insufficiency of Antitrust Analysis for Patent Misuse, 55 Hastings L.J. 399, 439-49 (2003).

146. See McFarling II, 363 F.3d at 1343. 
The court in McFarling I rejected such claims as unproven, but this holding was primarily an evidentiary matter, without any serious analysis as to the dimensions of the relevant markets and Monsanto's market power in those markets. ${ }^{147}$ In an increasingly consolidated seed industry, the concomitant concentration of patents and market power in the hands of a very few firms deserves more serious scrutiny. Under such conditions, the technological "lock-out" effect of GURTs may be even greater than those of exclusive rights under patent law. I have suggested elsewhere that anticompetitive conduct and misuse constraints ought to apply in the context of digital rights management,148 and they could equally well prove applicable in some situations of GURTs deployment.

\section{CONCLUSION}

Deployment of genetic use restriction technologies raises serious policy concerns over the substitution of private technological regimes for publicly enacted legal regimes. The key cases regarding the application of patent, trade secrecy, and attendant licenses are analytically muddled even on their own facts, and offer dubious guidance outside their specific holdings. Indeed, these cases leave open and unanswered numerous serious questions about the routine deployment of "seedwrap" licenses and about the intellectual property regimes applicable to transgenic plant varieties, let alone any new or more exotic set of issues. Extending the results of such cases to technological substitutes is highly problematic, leaving the legal propriety of GURTs deployment in substantial doubt for the foreseeable future.

147. McFarling I, 302 F.3d 1291,1291, 1298 (Fed. Cir. 2002).

148. See generally Anticircumvention, supra note 25. 